
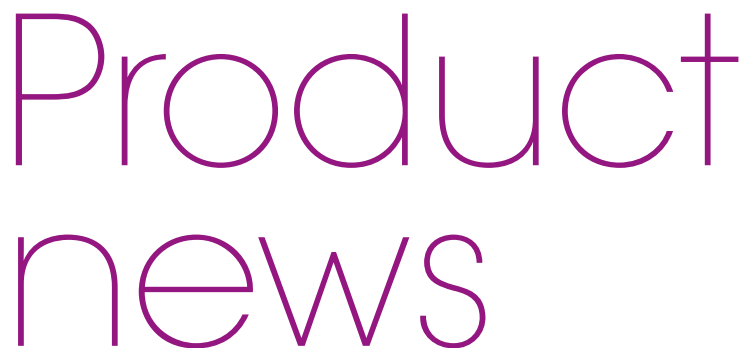

Product news is provided as a service to readers using text and images from

the manufacturer, supplier or distributor and does not imply endorsement by

BDJ Team. Normal and prudent research should be exercised before purchase

or use of any product mentioned.

\title{
ENDURING TREATMENT NEEDS A FOUNDATION OF ORAL HEALTH
}

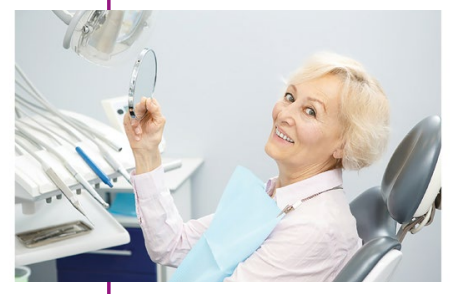

Empowered patients are choosing elective dental treatment to improve their health and wellbeing.

For successful clinical outcomes, effective daily cleaning will keep the result beautifully maintained, so recommend a regular routine using high-quality products. Premium oral health brand TANDEX has brushes and interdental brushes, with clear packaging to help them find the right size for each space.

Packs show a PHD (passage hole diameter) and ISO number, which together form a unique combination, identified by the colour of the brush handle.

Support your patients to find the best tools and establish excellent behaviours for life, with TANDEX.

For more information on Tandex's range of products, visit https://tandex.dk/.

\section{AIR HAS NEVER BEEN EASIER}

DentalAir has made your air supply easier than ever before with its new service - 'Air to the Chair'.

By paying just $\mathfrak{£} 5$ per week for every chair you need an air supply for, you not only benefit from a installation of a new air supply but also all of the associated maintenance, necessary certification and support. Your 'Air to the Chair' can be taken out in 36 month or
60 month contracts, but these can be adapted during this time to suit any changes needs for example, if you require an air supply to more chairs.

So, what are you waiting for? Access the 'Air to the Chair' portal on the DentalAir website here: www.dentalair.com.

For more information, contact DentalAir at info@dentalair.com or call 08009757530.

\section{WIPE AWAY YOUR INFECTION CONTROL FEARS}

Award-winning CaviWipes from Kerr are all-in-one, ready-to use disinfectant wipes pre-saturated with CaviCide solution for the effective removal of dirt as well as quick and broad-spectrum disinfection.

Available in a flat pack or cannister for convenience, CaviWipes have a low alcohol content (17\%), preventing bioburden from becoming insoluble and stubbornly adherent to surfaces, for a more effective clean and disinfection. They do not contain aldehydes, phenols, bleach or other toxic chemicals.

CaviCide is effective against Human Coronavirus and with these extra-large and thick wipes, fungicidal, bactericidal, virucidal and tuberculocidal disinfection is achieved in just three minutes. In addition, the nonwoven fabric allows the tissue to remain intact, without bunching up or drying out during use.

For further information on CaviWipes, visit www.kerrdental.com/en-uk or contact your local rep.

\section{CHANGING SMILES} DISCREETLY

\section{You may be}

experiencing more

enquiries about

orthodontics, as

patients want to invest

in improving their

smile.

With the Incognito Appliance System from 3M Oral Care, your patients won't have to feel self-conscious about wearing an appliance, because it is fitted behind the teeth. It will be customised to the oral cavity and will gently move their teeth into the desired position. The results will be predictable, enduring and even lifechanging, offering an ideal solution for a range of patients.

For more information, call 0845873 4066 or visit http://solutions.3m.co.uk/ wps/portal/3M/en_GB/orthodontics_EU/ Unitek/3M representatives continue to be available via video calling technologies for your convenience.

$3 \mathrm{M}$ and Incognito are trademarks of the $3 \mathrm{M}$ Company.

\section{POWERFUL PROTECTION}

The Steri-7 Xtra range of disinfectants from Initial Medical can be used on a variety of surfaces and delicate equipment and effectively eliminate threats to infection control.

The range comprises of surface cleaners, hand washes, wipes and more. Even though the powerful formula kills $99.9999 \%$ of bacteria, viruses and other pathogens, it is still gentle enough to be used on delicate equipment.

As an added bonus the Steri-7 Xtra range is imbued with Reactive Barrier Technology - this means that after application they prevent pathogens from recolonising surfaces for up to 72 hours providing exceptional protection between cleaning cycles.

For further information visit www. initial.co.uk/medical or tel: 08708504045 . 